\title{
Geoscience Literacy Profile of Junior High School Students
}

\author{
Desy Suryani ${ }^{1}$, Eko Hariyono ${ }^{2}$ \\ 1,2, Universitas Negeri Surabaya, Surabaya, Indonesia
}

\begin{tabular}{|c|c|}
\hline (A) check for updates oper $\partial$ access cc) (i) (2) & DOI : https://doi.org/10.46245/ijorer.v2i3.105 \\
\hline Sections Info & ABSTRACT \\
\hline $\begin{array}{l}\text { Article history: } \\
\text { Submitted: February 25, } 2021 \\
\text { Final Revised: April 7, } 2021 \\
\text { Accepted: April 18, } 2021 \\
\text { Published Online: May 31, } 2021\end{array}$ & $\begin{array}{l}\text { The purpose of this research is to find out the geoscience literacy profile of } \\
\text { junior high school students in Surabaya. The method used in this research is } \\
\text { quantitative method. The test is done online through google form. The } \\
\text { problem used in the test instrument is an adaptation of the TIMSS (Trends in } \\
\text { Mathematics and Science Study) question in the Earth Science sub-discussion. }\end{array}$ \\
\hline $\begin{array}{l}\text { Keywords: } \\
\text { Cognitive domain } \\
\text { Earth Science } \\
\text { Geoscience Literacy } \\
\text { TIMSS }\end{array}$ & $\begin{array}{l}\text { The question instrument contains } 10 \text { points of multiple choice questions, and } 3 \\
\text { items of description questions that are the result of the development of } \\
\text { indicator slices of TIMSS (Trends in Mathematics and Science Study) } 2019 \text { and } \\
\text { basic competency indicators of curriculum 2013. The study subjects were } 85 \\
\text { respondents who were grade VIII students of State and Private Junior High in }\end{array}$ \\
\hline 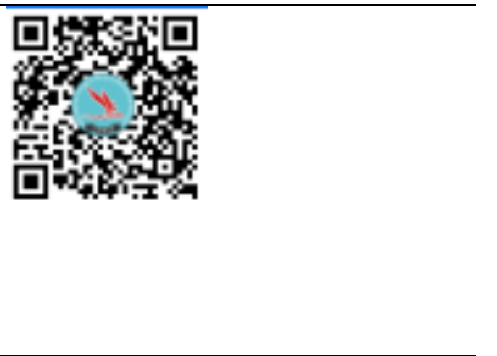 & $\begin{array}{l}\text { Surabaya. The results showed that the geoscience literacy capability profile of } \\
\text { junior high school students in Surabaya with an average score of } 58.2 \% \text { is } \\
\text { included in the low criteria, there are two indicators that have low } \\
\text { achievement criteria, namely identifying or describing changes in the earth's } \\
\text { surface, and the impact of geological events; and describe the process of } \\
\text { hydrological cycles and know the sun as a source of energy for the hydrology } \\
\text { cycle, sufficient achievement criteria, contained in the domain of cognitive } \\
\text { knowing and reasoning. While the criteria for achievement are low, it is found } \\
\text { in the cognitive domain applying. }\end{array}$ \\
\hline
\end{tabular}

\section{INTRODUCTION}

Geoscience is widely defined as a study of Earth and planetary systems. Geoscience is a broad science, where geosciences also learn about the relationship of a process in the scale of a planetary system to explore the chemical reactions that occur in a mineral. Understanding of the earth, is a holistic understanding of the Earth's system covering the oceans, atmosphere, hydrosphere, and biosphere, as well as inter-system interactions (Manduca. 2012). Essential components in this geoscience include geoscience knowledge, predicting skills, and decision making skills. These essential components are necessary to face present and future challenges (Fermeli et al, 2014; Hariyono, 2017).

Anggrayni (2020) in her research also revealed that an understanding of geoscience is indispensable in facing the challenges and developments of the times. Some of these challenges include global needs that depend on the utilization of energy, where the energy produced was produced, and both of them happened on Earth. Thus, the condition indirectly also involves an understanding of geosciences. The next challenges are water, soil, and mineral sources that are beginning to be scarce in some areas due to rising global populations and industries, as well as climate change.

In the Educational field in 2003, Indonesia has proposed a new curriculum. The new curriculum changes the learning steps of exploration, elaboration, and confirmation. Teaching-learning approach that suitable in this condition was scientific approach (Wiyanto, 2017). Scientific approach is an approach that aims to knowledge through several steps such as: observing, questioning, experimenting, associating, and 
communicating. However, this is not enough to answer the challenges of the future (Putra, 2020).

One of the challenges that will be faced by the young generation of Indonesia in the future is literacy skill. The younger generation of Indonesia must be a literate generation, who are literate in literacy. The government in this regard, has prepared a strategy to build a culture of literacy in schools, in order to form a literate generation. There are 3 ways, such as adjusting the physical environment in order to support literacy, trying to make the social and affective environment as a literate model of communication and interaction, and trying to make the schools as a literate academic environment system (Directorate General of Primary and Secondary Education ministry of Education and Culture, 2016). In one of the studies found a fact that in the application of literacy-based learning, teachers will ask their students to find some information using offline and online source in the library. This is such a useful activities to strengthen student's learning abilities (Subekti, et al, 2019).

According to Rod Welford, who The Minister Education and Culture Queensland, Australia, literacy is at the heart of students' ability to learn and succeed in school and later levels, so it needs to be done to provide opportunities for learners to master literacy from an early age to 12 years so that it can face challenges in the 21st century. In the 21st century, education has a goal to encourage student's skill. The most necessary thing to prepare in order to face the challenges on the 21st century is encouraging student's skill so that they have a deep knowledge and understanding. The main goal is making the student as a long live learner (Hariyanti, et al, 2019). Rod Welford also said that the priority of education is to improve students' literacy skills beyond standards, putting learners into different circumstances or conditions. Rod Welford also added that although the backgrounds of students are different, but the government must still strive for all learners to get a sufficient level of literacy to face the challenges that exist in the 21st century, because without adequate literacy skills, students will not be able to face the challenges that exist in the 21st century.

One of the areas of literacy that has been described by Kirsch was science literacy. Science Literacy derived from two words, namely literatus, which means marked with letters, literacy, or educated, and scientia which means to have knowledge. So science literacy is each individual's ability to understand and apply knowledge in solving problems related to science and technology in everyday life (OECD, 2016). Dragos and Mih (2015) defined Scientific literacy as a skills to apply someone's scientific knowledge in real situations. Someone had to use some strong evidence and data to evaluate the credibility of an information or scientific arguments. Also, (National Academy of Sciences, 1996) defines science literacy as knowledge and understanding of concepts and processes in taking personal decisions relating to social, cultural and the economy.

Science literacy was divided to some areas such as environment, climate, and earth. Science literacy which is related to geology or earth is called geoscience literacy or earth-science literacy. Geology as an geoscience was an integrated science such as biology, chemistry, and physics as they apply and explain about the Earth (Reis, et al, 2014). Ross (2010) defines geoscience literacy as an understanding of the earth, the dynamics of the earth, the impact of earth change on humans, and the impact of human activity on the earth. Geoscience literacy is an important thing, especially in Indonesia, because based on BMKG (Badan Meteorologi Klimatologi dan Geofisika) exposure 
(2013) Indonesia was located in the ring of fire area and the meeting point between the three main tectonic plates. This makes Indonesia was often hit by earthquakes, tsunamis, and volcanic eruptions. Based on this, geoscience literacy is considered to be necessary, so that people not only know about the natural disaster phenomena, but also can understand and explain the phenomenon as an effort to be aware of everything that happened to the environment.

Nowdays, geoscience literacy become important skill that everyone should to have. This is related to the availability of our natural resources to support a sustainable life, climate change, also human activities that have a big impact to the Earth. Increased geoscience literacy skill will help anyone to face that kind of critical issues (Wysession, et al, 2012). The importance of geoscience literacy as part of science education has been a concern, therefore geoscience literacy is one of the benchmarks regarding the quality of science education. So it is very important for students and institutions to cultivate geoscience literacy in daily learning activities, so that students can form who master the ability of geoscience literacy. Through this study, researchers intend to know the profile of geoscience literacy of learners, related to aspects of geoscience literacy in TIMSS, namely the aspects of knowing, applying and reasoning. The results obtained later can be used to describe the ability of geoscience literacy in each aspect.

\section{RESEARCH METHOD \\ General Background}

This research uses quantitative method through test instruments conducted online on grade VIII junior high school students in Surabaya whom have obtained earth layer material or have completed basic competence (KD) 3.10 Explaining the layers of earth, volcanoes, earthquakes, and risk reduction measures before, at the time, and postdisaster according to the threat of disaster in the region. The problem used in the test instrument is an adaptation of the TIMSS question in the Earth Science sub-discussion. It provides the measure of the geoscience literacy skill of junir high school students. This research uses a random sampling to determine the subject of research.

\section{Sample / Participants / Group}

The study subjects were 85 respondents who were grade VIII students of State and Private Junior High in Surabaya whom have obtained earth layer material or have completed basic competence (KD) 3.10 Explaining the layers of earth, volcanoes, earthquakes, and risk reduction measures before, at the time, and post-disaster according to the threat of disaster in the region

\section{Instrument and Procedures}

The problem used in the test instrument is an adaptation of the TIMSS question in the Earth Science sub-discussion. The isntrument that used was developed through ADDIE model such as the figure 1 .

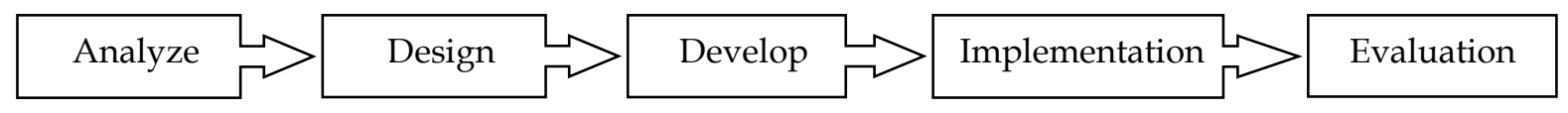

Figure 1. Flowchart of instrument's development process. 
TIMSS test has already tested for the validity, so in this research, the validity of the test was measured by expert judgement. Based on the judgement, the instrument was valid. The instrument reliability was measured by ANATES software. Its reability was 0,74 which categorized as highly reliable (Jacobs and Chase, 1992). The question instrument contains 10 points of multiple choice questions, and 3 items of description questions that are the result of the development of slices of indicators about TIMSS 2019 and basic competency indicators curriculum 2013 from basic competence (KD) 3.10. Here are the slices of TIMSS 2019 and basic competence (KD) 3.10 indicators:

Table 1. The slices of TIMSS 2019 and KD 3.10 indicators.

\begin{tabular}{|c|c|}
\hline KD 3.10 Indicator & TIMSS 2019 Indicator \\
\hline $\begin{array}{l}\text { 3.10.1 Explaining the characteristics of the } \\
\text { earth's constituent layers. }\end{array}$ & $\begin{array}{l}\text { 1. Deciques the structure of the earth and the } \\
\text { characteristics of its parts. }\end{array}$ \\
\hline 3.10.2 Explaining atmospheric characteristics. & $\begin{array}{l}\text { 2. Linking changes in atmospheric conditions } \\
\text { to altitude changes. }\end{array}$ \\
\hline $\begin{array}{l}\text { 3.10.3 Explaining the characteristics of the } \\
\text { lithosphere. }\end{array}$ & $\begin{array}{l}\text { 3. Identify or describe changes in the earth's } \\
\text { surface, and the impact of geological events }\end{array}$ \\
\hline \multicolumn{2}{|l|}{$\begin{array}{l}\text { 3.10.4 Explaining the characteristics of } \\
\text { earthquakes and their disaster risk } \\
\text { reduction. }\end{array}$} \\
\hline \multicolumn{2}{|l|}{$\begin{array}{l}\text { 3.10.5 Explaining the characteristics of } \\
\text { volcanoes and their disaster risk } \\
\text { reduction. }\end{array}$} \\
\hline $\begin{array}{l}\text { 3.10.6 Explaining the characteristics of the } \\
\text { hydrosphere and its disaster risk } \\
\text { reduction. }\end{array}$ & $\begin{array}{l}\text { 4. Describe the process of hydrological cycle } \\
\text { and know the sun as a source of energy for } \\
\text { the hydrology cycle. }\end{array}$ \\
\hline
\end{tabular}

\section{Data Analysis}

Geoscience literacy score is calculated by percentage technique for each indicator, then the final score result will be interpreted with certain criteria according to the following Table 2.

Table 2. Criteria of geoscience literacy score.

\begin{tabular}{cc}
\hline Criteria Interval & Criteria \\
\hline $86 \% \leq \mathrm{N}<100 \%$ & Very Good \\
$76 \% \leq \mathrm{N}<85 \%$ & Good \\
$60 \% \leq \mathrm{N}<75 \%$ & Enough \\
$55 \% \leq \mathrm{N}<59 \%$ & Low \\
$\mathrm{N} \leq 54 \%$ & Very Low \\
\hline
\end{tabular}

\section{RESULTS AND DISCUSSION}

The questions of the test were adapted from The TIMSS 2019 Science Framework to sub Earth Science. The average geoscience literacy score obtained was 58.2\%. Thus, the geoscience literacy profile of junior high school students in Surabaya is included in the low criteria. As the part of science literacy, this result was according to the research 
onducted before, that the literacy achievement was still low (Odja \& Payu, 2014; Nuraini, 2018). Also, Hariyono (2014) in his research stated that geoscience lietracy skill in Indonesia still low. The following is a graph of the distribution of geoscience literation scores percentage of junior high school students in Surabaya based on indicators used:

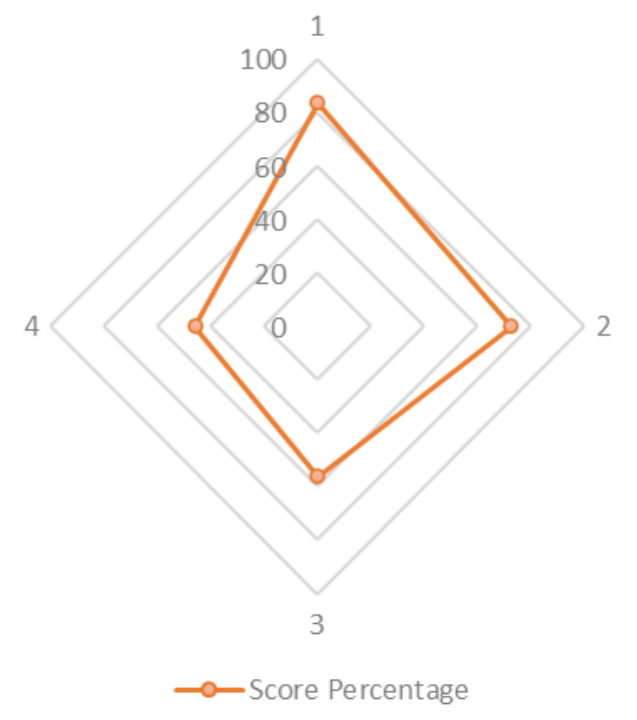

Figure 2. Score percentage distribution in each indicator.

To further clarify the score results of each indicator, the following is the exposure of geoscience literacy capability profile results based on the indicators used:

Describe the structure of the earth and the characteristics of its parts

In this indicator, a score percentage of $83.5 \%$ or as many as 71 respondents can answer correctly. So, in this indicator, junior high school students in Surabaya have a good ability in describing the structure of the earth and the characteristics of its parts.

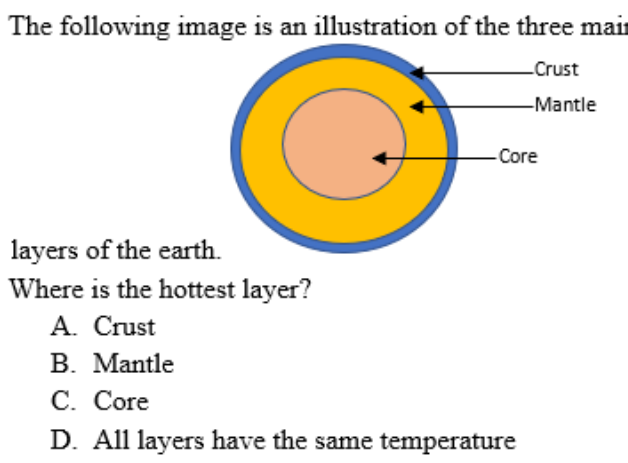

Figure 3. The example of indicator 1 question.

Linking changes in atmospheric conditions to changes in altitude

In the second indicator, the average score percentage is $72.65 \%$. The average is obtained from 4 question points on this indicator, where each question has a percentage of $80 \%$, $64.7 \%, 81.2 \%$, and $64.7 \%$. Based on these results, students' geoscience literacy skills on indicators linking changes in atmospheric conditions to changes in altitude are included in the good criteria. 
Dodi is a professional climber. He will climb one of the highest mountain. He must carry a breathing apparatus when climbing the top of mountain. Why is this necessary?
A. Low oxygen levels at the top of the mountain
B. There is a small amount of nitrogen at the top of the mountain
C. There's a hole in the ozone layer
D. There is no oxygen at the top of the mountain

Figure 4. The example of indicator 2 question.

Identify or describe changes in the earth's surface, and the impact of geological events

In this third indicator, the average score percentage was $56.3 \%$ The average is obtained from 3 question points on this indicator, where each question has a percentage of $82.4 \%$, $42.4 \%$, and $44.3 \%$. On this indicator, students's geoscience literacy skills include low criteria. Students were supposed to find the evidence and break down the concept that already they have. The low achievement of this indicator implicates that the students have low scientific competence in explaining phenomena.

Where are active volcanoes often found?
A. Near the river
B. The area where tectonic plates meet
C. In the ocean
D. The meeting area of land and water

Figure 5. The example of indicator 3 question.

Describe the process of hydrological cycle and know the sun as a source of energy for the hydrology cycle

In this indicator, the average score percentage is $45.8 \%$. The average is obtained from 5 question points in this indicator, where each question has a percentage of $43.5 \%, 35.3 \%$, $54.9 \%, 35.25 \%$, and $60 \%$. Based on these results, students' geoscience literacy skills on indicators describe the process of hydrological cycles and recognize the sun as an energy source for hydrological cycles including very low criteria.

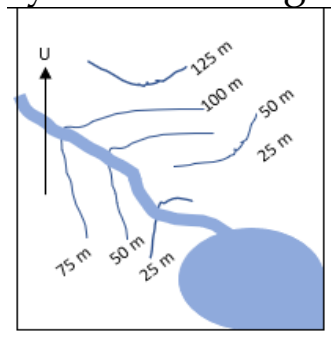

The following is a drawing of the contours of the hills and

valleys. Each contour of the line shows the height of the

land surface above sea level.

Where is the river current?
A. Northeast
B. Southeast
C. Northwest
D. Southwest
E. It can't be explained from the picture

Figure 6. The example of indicator 4 question. 
The very low achievement was on the third and fifth indicator, it implicates that the students have low scientific competence in explaining phenomena. This competence may relate with their science knowledge about the earth (Wulandari \& Sholihin, 2016). Students were supposed to find the evidence and break down the concept that already they have. The question on the test asks the student to link their knowledge with a common phenomena. Based on the cognitive theory, students will use their prior knowledge to process a new knowledge by linking them. The student's prior knowledge was defined by the learning process. It might happend that the teacher mostly train the student by low level cognitive domain (Marlina et al, 2017). Based on the interview with teacher and some students, known that the learning process just train the student by using low level cognitive domain such as C1 and C2.

In addition to the exposure results according to the indicators, the following is a table of exposure to geoscience literacy scores based on three cognitive domains adapted from The TIMSS 2019 Science Framework:

Table 3. The score criteria based on TIMSS cognitive domains.

\begin{tabular}{ccc}
\hline Cognitive Domain & Persentage (\%) & Criteria \\
\hline Knowing & 65.18 & Enough \\
Applying & 42.40 & Very Low \\
Reasoning & 67.35 & Enough \\
\hline
\end{tabular}

Based on the table, it is known that the literacy profile of junior high school students in Surabaya in accordance with the cognitive domain has not reached the criteria either. The lowest achievement or criterion is applying cognitif domain. The applying domain involve the application of scientific knowledge in some situations and relationship demonstration. Students are supposed to relate, classify, compare, and find the possible solution (Kablan \& Kaya, 2013). Same as the problem before, the learning process as the main reason. The lack of implementation in learning-teaching process which include science process (Siagian et al, 2017). The low level of student's geoscience literacy also may caused by student's behaviour, because they never do the literacy test model (Devinda \& Violita, 2019). The student said that they usually do a test which the answer available on their book. The learning process should to apply scientific approach to improve scientific process skill (Arohman et al, 2016). Morever, geoscience literacy as a part of science literacy actually was not only built by student's knowledge but also the support of all parties to improve the student's ability (Yanti et al, 2018).

\section{CONCLUSIONS}

Based on the exposure of the results, that the geoscience literacy capability profile of junior high school students in Surabaya with an average score of $58.2 \%$ is included in the low criteria, there are two indicators that have low achievement criteria, namely identifying or describing changes in the earth's surface, and the impact of geological events; and describe the process of hydrological cycles and know the sun as a source of energy for the hydrology cycle, sufficient achievement criteria, contained in the domain of cognitive knowing and reasoning. While the criteria for achievement are low, it is found in the cognitive domain applying. Geoscience literacy as a part of science literacy actually was not only influenced by student's knowledge but also the support of all parties to improve the student's ability. It takes efforts in the future to develop teaching 
materials based on geoscience literacy as a source of student learning, so that students are better acquainted with geoscience literacy.

\section{REFERENCES}

Anggraini, N., \& Wasis. (2014). Pengembangan soal IPA-Fisika nodel TIMSS (Trends In Interntional Mathematics and Science Study). Jurnal Inovasi Pendidikan Fisika, 3(1), 15-18.

Anggrayni, Silvia \& Madlazim, Madlazim \& Hariyono, Eko. (2019). Science teacher's conception about importance of Geoscience learning: A case study of junior high schools in Surabaya Indonesia. Journal of Physics: Conference Series, 1417(012090). DOI: 10.1088/17426596/1417/1/012090.

Anggrayni, S., \& Hariyono, Eko. (2020). The students's voice of volcanology in education for sustainable development context. Journal of Physics: Conf. Ser, 1491(012032).

Anjarsari, P. (2014). Literasi sains dalam kurikulum dan pembelajaran IPA SMP. Yogyakarta: Universitas Negeri Yogyakarta.

Ardiyanti, Y \& Suyanto, S \& Suryadarma, IGP. (2019). The role of students science literacy in Indonesia. Journal of Physics: Conference Series, 1321. 032085. DOI: 10.1088/17426596/1321/3/032085.

Arohman, M., Saefudin \& Priyandoko. (2016). Kemampuan literasi sains siswa pada pembelajaran ekosistem. Proceeding Biology Education Conference, 13, 90-92.

Binkley, M., Erstad, O., Herman, J., Raizen, S., Ripley, M., Miller-Ricci, M., \& Rumble, M. (2012). Defining twenty-first century skills. In Griffin, P., McGaw, B., \& Care, E. (Eds.). Assessment and Teaching of 21st Century Skills. New York: Springer Science-Business media, 17-66.

BMKG. (2013). Potensi bencana alam di Indonesia. (Online).

Chiappeta, E., Filman, D., \& Sethna, G. (1991). A method to quantify major themes of scientific literacy in science textbooks. Journal of Research in Science Teaching, 28(8), 713-725.

Cummings ML, Goodrich M, \& Burmester D. (2003). Geoscience for elementary educators: A course assessment. The Journal of Mathematics and Science: Collaborative Explorations, 6, 127140.

Demir, E. (2016). Characteristics of 15-year-old students predicting scientific literacy skills in Turkey. International Education Studies, 9(4), 99. https://doi.org/10.5539/ies.v9n4p99

Devinda, Maya Sari \& Violita. (2019). Analysis of science literacy abilities of class VIII junior high school students in Padang. International Journal of Progressive Science an Technology, 15(1), 196-203.

Direktorat Jenderal Pendidikan Dasar dan Menengah Kementrian Pendidikan dan Kebudayaan. (2016). Desain induk gerakan literasi sains sekolah. Jakarta: Direktorat Jenderal Pendidikan Dasar dan Menengah Kementrian Pendidikan dan Kebudayaan.

Dragos, Viorel dan Mih, Viorel. (2015). Scientific literacy in school. Procedia - Social and Behavioral Sciences, 209, 167 - 172.

Earth Science Literacy Principles. (2009). Earth science literacy principles. Alexandria: NSF Publishing.

Fenanlampir, Alberthus \& Batlolona, John \& Imelda, Imelda. (2019). The struggle of Indonesian students in the context of TIMSS and PISA has not ended. International Journal of Civil Engineering and Technology, 10, 393-406. 
Fives, H., Huebner, W., Birnbaum, A. S., \& Nicolich, M. (2014). Developing a measure of scientific literacy for middle school students. Science Education, 98(4), 549-580. https://doi.org/10.1002/sce.21115

Hariyanti, Ima, et al. (2019). The importance of early reading learning in the face of 21st century education. AL-ASASIYYA: Journal Of Basic Education. DOI: 196. 10.24269/ajbe.v3i2.1879.

Hariyono, Eko. (2014). Membangun Literasi geosains dalam memahami dinamika gunung berapi. Prosiding Semnas IV Pendidikan Sains. Surabaya: FMIPA, UNESA.

Hariyono E, Liliasari, Tjasyono B, \& Madlazim. (2016). Volcanic eruption crisis and the challenges of geoscience education in Indonesia. AIP Conference Proceedings. https://doi.org/10.1063/1.4941190.

Hariyono, E. (2018). Pengembangan Volcano Learning Project (VLP) dalam Pembelajaran Geosains bagi Mahasiswa Calon Guru Fisika. SemanticsScholar.

Hariyono, E., Fani, Wijaya, Candra \& Fujii, Hiroki. (2018). Designing geoscience learning for sustainable development: A professional competency assessment for postgraduate students in science education. JPFA, 8, 61-70. DOI: 10.26740/jpfa.v8n2.p61-70.

Hayat, B. \& S. Yusuf. (2011). Benchmark internasional mutu pendidikan. Jakarta: Bumi Aksara.

Hidayat, Y., Siahaan, P., \& Liliawati, W. (2018). Profile of scientific literacy competence student on temperature and heat matter. International Conference on Mathematics and Science Education of Universitas Pendidikan Indonesia, 3, 264-268.

Holbrook, J., \& Miia Rannikmae. (2009). The meaning of scientific literacy. International Journal of Environmental \& Science Education, 4(3), 275-288.

Holbrook, J., \& Rannikmae, M. (2016). The nature of science education for enhancing scientific literacy. International Journal of Science Education, 29(11). https://doi.org/10.1080/09500690601007549

Ilmi S. P., Miftakhul, Widodo, W. \& Jatmiko, B. (2016). The development of guided inquiry science learning materials to improve science literacy skill of prospective mi teachers. Jurnal Pendidikan IPA Indonesia. DOI: 10.15294/jpii.v5i1.5794.

Jacobs, L. C., and Chase, C. (1992). Developing and Using Tests Effectively: A Guide for Faculty. San Francisco: Jossey-Bass

Jonane, Lo. (2015). Analogies in Science Education, 119(3). Lietuvos Edukologijos Universitetas. Latvia: Daugavpils

Kablan, Zeynel \& Kaya, Sibel. (2013). Science achievement in TIMSS cognitive domains based on learning styles. Eurasian Journal of Educational Research, 97-114. DOI: 10.14689/ejer.2013.53.6.

Kemdikbud. (2017). Materi Pendukung Literasi Sains. Jakarta : Kementrian Pendidikan dan Kebudayaan.

Kementerian Pendidikan dan Kebudayaan. (2014). Implementasi Kurikulum 2013. Jakarta: Kementerian Pendidikan dan Kebudayaan.

Kirsch, et al. (2001). Technical report and data file user's manual for the 1992 national adult literacy survey. Washington DC: U.S. Department of Eduction.

Klemm, William R. (2007). What good is learning if you don't remember it?. The Journal of Effective Teaching, 7(1), 61-73.

LaDue ND \& Manning CB. (2015). Next generation science standards: A call to action for the geoscience community. GSA Today, 25(2), 28-29. 
Locke S, Libarkin J, \& Chang CY. (2012). Geoscience education and global devlopment. Journal of Geoscience Education, 60, 199-200.

LUSCHEI, T. F. (2017). 20 Years of TIMSS: Lessons for Indonesia. Indonesian Research Journal in Education, 1(1), 6-17. https://doi.org/10.22437/irje.v1i1.4333

Manduca, Cathryn. (2012). Geoscience and Geoscientist: Uniquely equipped to study earth. The Geological Society Of America Special Paper, 486.

Marlina, R., Puspaningrum, H., \& Hamdani, H. (2017). Differentiation of test items between the high school biology olimpiad in North Kayong and The National Science Olimpiad. Jurnal Pendidikan IPA Indonesia, 6(2), 245-251.

McFarlane, D. A. (2013). Understanding the challenges of science education in the 21sttCentury: New opportunities for scientific literacy. International Letters of Social and Humanistic Sciences, 4, 35-44. https:// doi.org/10.18052/www.scipress.com/ILSHS.4.35

National Research Council. (2012). A framework for K-12 science education: Practices, crosscutting concepts, and core ideas. Washington DC: National Academies Press.

National Academy of Sciences. (1996). National science education standards. Washington DC: National Academy Press.

Nixon, Ryan \& Barth, Katie. (2014). A comparison of TIMSS items using cognitive domains. School science and mathematics, 114, 65-75. DOI: 10.1111/ssm.12054.

Nugraha, H., Raharjo, R., \& Rachmadiarti, F. (2018). Assessing early level of literacy: a case study on science literacy in biotechnology. International Conference on Mathematics and Science Education of Universitas Pendidikan Indonesia, 3, 519-524.

Nuraini, D \& Rahardjo, Sentot \& Susanti, V. (2018). Student's profile about science literacy in Surakarta. Journal of Physics: Conference Series, 1022(012016). DOI: 10.1088/17426596/1022/1/012016

Nuryanti, A \& Kaniawati, I \& Rahma Suwarma, Irma. (2019). Junior high school students' scientific literacy on earth science concept. Journal of Physics: Conference Series, 1157(022044). DOI: 10.1088/1742-6596/1157/2/022044.

Odja, A. H., \& Payu, C. S. (2014). Analisis kemampuan awal liteasi sains siswa pada konsep IPA. Prosiding Seminar Nasional Kimia, 1, 40-47.

OECD. (2016). PISA 2015. PISA results in Focus. www.oecd.org/pisa/pisa-2015-results-infocus.pdf.

OECD. (2016). PISA 2015 assessment and analytical framework: Science, reading, mathematic and financial literacy. Paris: OECD Publishing.

Putra, M. D., Wiyanto, W., \& Linuwih, S. (2020). The effect of discovery learning on 21st century skills for elementary school students. Journal of Primary Education, 9(2), 201-208. https://doi.org/10.15294/jpe.v9i2.37349

Reis, J, et al. (2014). Science education in a museum: Enhancing earth sciences literacy as a way to enhance public awareness of geological heritage. Geoheritage, 6, 217-223. DOI: 10.1007/s12371-014-0105-0

Ridho, S., Aminah, N. S., \& Supriyanto, A. (2018). The profile of scientific literacy skill student at SMA Batik 2 Surakarta. Jurnal Penelitian E Pengembangan Pendidikan Fisika, 4(2), 47 - 54. https://doi.org/10.21009/1.04201

Ross. (2010). Earth science literacy: Big ideas and supporting concepts. American Paleontologist, 18(1). 
Rusilowati, A., Mulyani, S. E. S., \& Nugroho, S. E. (2015). Pengembangan Bahan Ajar IPA Berbasis Literasi Sains. Laporan Penelitian. Semarang: Universitas Negeri semarang.

Rusilowati, A., Kurniawati, L., Sunyoto E. N., \& Widiyatmoko, A. (2016). Developing an Instrument of Scientific Literacy Asessment on the Cycle Theme. International Journal of Environmental \& Science Education, 11(12), 5718-5727.

Rustaman, N.Y., Rusdiana, D., Liliawaty, W., \& Efendi, R. (2016). A workshop program on Authentic Assessment for Science Teacher. MSCEIS.

Setiawan, B., Innatesari, D., Sabtiawan, W., \& Sudarmin, S. (2017). The development of local wisdom-based natural science module to improve science literation of students. Jurnal Pendidikan IPA Indonesia, 6(1), 49-54. https://doi.org/10.15294/jpii.v6i1.9595

Siagian, P., Silitonga, M., \& Djulia, E. (2017). Scientific literacy skills of seventh grade junior high school (SMP Negeri) students in North Labuhanbatu Regency. International Journal of Humanities Social Sciences and Education, 4(11), 176-182.

Subekti, Hasan \& Susilo, Herawati \& Ibrohim, Ibrohim \& Suwono, Hadi \& Martadi, \& Purnomo, Aris. (2019). Challenges and Expectations towards Information Literacy Skills: Voices from Teachers' Training of Scientific Writing. International Journal of Learning, Teaching and Educational Research, 18, 99-114. DOI: 10.26803/ijlter.18.7.7.

Sunawan, A., \& Rosjanuardi, R. (2019). The achievement analysis of Indonesian TIMSS 2011 in mathematics towards didactical situation. Journal of Physics: Conference Series. 1188(012041). DOI: 10.1088/1742-6596/1188/1/012041.

Wiyanto, \& Nugroho, S.E. \& Hartono, Mr. (2017). The scientific approach learning: how prospective science teachers understand about questioning. Journal of Physics: Conference Series, 824(012015). DOI: 10.1088/1742-6596/824/1/012015.

Wulandari, Nisa \& Sholihin, Hayat. (2016). Analisis kemampuan literasi sains pada aspek pengetahuan dan kompetensi sains siswa SMP pada materi kalor. Edusains, 8(1), 66-73.

Wysession, Michael, et al. (2012). Developing and applying a set of earth science literacy principles. Journal of Geoscience Education, 60, 95-99.

Yanti, Rosmalah, Prihatin, T., \& Khumaedi. (2018). Profile of science literacy skill domain knowledge of SMPN 2 Bua Ponrang. Journal of Primary Education, 7(1), 34-40.

\footnotetext{
${ }^{*}$ Desy Suryani (Corresponding Author)

Universitas Negeri Surabaya,

Postgraduate Programme, Science Education Study Program

Continuing Program Development, Jl. Unesa Lidah Wetan, Surabaya, East Java, Indonesia

Email: desy.19047@mhs.unesa.ac.id
}

\section{Dr. Eko Hariyono, M.Pd.}

Universitas Negeri Surabaya,

Postgraduate Programme, Science Education Study Program

Continuing Program Development, Jl. Unesa Lidah Wetan, Surabaya, East Java, Indonesia

Email: ekohariyono@unesa.ac.id 